\title{
Nepeta menthoides Boiss. \& Buhse, an endemic species in Iran: A review of traditional uses, phytochemistry and pharmacology
}

\author{
Zahra Memariani $^{1,2}{ }^{(0)}$, Atena Rahimi ${ }^{3 *(0)}$, Mohammad Hosein Farzaei ${ }^{4,5}$, Niloofar Zakaria Nejad ${ }^{1}$ \\ ${ }^{1}$ Traditional Medicine and History of Medical Sciences Research Center, Health Research Institute, Babol University of Medical Sciences, Babol, Iran \\ ${ }^{2}$ Department of Persian Medicine, School of Persian Medicine, Babol University of Medical Sciences, Babol, Iran \\ ${ }^{3}$ Cellular and Molecular Biology Research Center, Health Research Institute, Babol University of Medical Sciences, Babol, Iran \\ ${ }^{4}$ Pharmaceutical Sciences Research Center, Kermanshah University of Medical Sciences, Kermanshah, Iran \\ ${ }^{5}$ Medical Biology Research Center, Kermanshah University of Medical Sciences, Kermanshah, Iran
}

\section{A R T I C L E I N F O}

Article Type:

Review

\section{Article History:}

Received: 18 January 2019

Accepted: 27 February 2019

\section{Keywords:}

Nepeta menthoides

Lamiaceae family

Ostokhodus

Terpenoids

Traditional medicine

\begin{abstract}
A B S T R A C T
Nepeta menthoides Boiss \& Buhse is one of the endemic species in Iran. Named Ostokhodus, it is almost used as substitute of the Lavandula stoechas -the original Ostokhodus- in traditional Persian medicine (TPM) over the time and widely used for the management of some ailments such as anxiety, depression, dementia and chronic pain. The aim of this study is to review the pharmacological and phytochemical evidence on Nepeta menthoides for the assessment of the recommended traditional indications of this herb. In this review, all the relevant articles that met our inclusion criteria [English or Persian articles, having full text, evaluating therapeutic effects of N. menthoides and dated mainly from the year 1980 to 2018] were included by searching studies in PubMed, Scopus, Google Scholar, Web of Science, and SID. The search terms were "Nepeta menthoides, "Ostokhodus". Triterpenes and monoterpenes were the most chemicals reported from essential oil of N. menthoides. Several pharmacological properties via in vitro, in vivo and clinical studies have been reported including antioxidant, anti-inflammatory, anti-nociceptive, antidepressant and anxiolytic, anticholinesterase, neuroprotective, memory enhancing, antiAlzheimer's disease, anticancer and effect on opioid dependence. Some proposed traditional indications of this herb in TPM books are in accordance with pharmacological evidence like anti-nociceptive, anti-seizure, anti-Alzheimer's disease, memory enhancing, neuroprotective, antidepressant, anxiolytic activity and anti-infective properties. Although some properties in TPM, such as anti-tussive and gastrotonic effects are not supported by scientific evidence, they need more investigations.
\end{abstract}

Implication for health policy/practice/research/medical education:

As one of the endemic species in Iran, Nepeta menthoides is widely used as medicinal plant by the vernacular name "Ostokhodus" in traditional Persian medicine. Reviewing the scientific evidence via collecting, classifying and summarizing published studies on the medicinal properties and possible side effects of this plant can be helpful for therapists and researchers in traditional medicine. It also provides basic information for further research as a coherent herbal monograph.

Please cite this paper as: Memariani Z, Rahimi A, Farzaei MH, Zakaria Nejad N. Nepeta menthoides Boiss. \& Buhse, an endemic species in Iran: A review of traditional uses, phytochemistry and pharmacology. J Herbmed Pharmacol. 2019;8(3):194-204. doi: 10.15171/jhp.2019.29.

\section{Introduction}

Plants have long been used for the treatment of various conditions and many researches are being done in pharmaceutical industries because of the belief that these natural remedies might have lesser side effects than current drugs (1). Lamiaceae family is one of the largest and specific flowering plants with about 220 genera and
4000 species all around the world (2,3). The genus Nepeta L. is one of the genera of Nepetoideae subfamilies and consists of about 300 species widely distributed in Europe, Asia and some areas of Africa $(3,4)$. Iran is one of the major sources of this genus with 79 species (5). Various species of the genus Nepeta have been used traditionally for their therapeutic effects including anticonvulsant, antitussive, 
anti-microbial and anti-asthma properties (6). Nepeta menthoides is one of the endemic species distributed in differentareas of Iran including Azarbaijan, Tabriz, Sabalan, and Marand $(7,8)$. Nepeta menthoides is a herbaceous, perennial, climbing plant with the height about $15-45 \mathrm{~cm}$ with the purple flowers (8). Archaeological excavation evidence suggests that some species of the Lamiaceae family were widely cultivated in the past locally (9). Many species of this family have been shown to possess similar essential oils (2,3). Many studies have been conducted on the chemical composition of the Nepeta sp. essential oils in Iran and other countries; based on these studies the main components of these species are nepetalactone, 1,8-cineole, $\beta$-pinene and geranyl acetate. Phenolic compounds such as flavonoids have also been reported as the main component of this genus (10). Nepeta menthoides is one of the plants named "Ostokhodus" through the time in TPM and widely used for the treatment of neurological disorders including seizure, chronic pain, depression and anxiety disorder $(11,12)$. The original Ostokhodus (Lavandula stoechas) was used in Persia for a long time as an imported drug (13). As an endemic medicinal plant and a common substitute of $L$. stoechas in Iran, this herb is of importance in traditional Persian medicine (TPM). Some researches on $N$. menthoides have been carried out to evaluate scientifically the traditional uses of this herb. The aim of this study is to review the pharmacological and phytochemical scientific evidence on N. menthoides. This review presents a comprehensive assessment report on phytochemical aspects, pharmacological activities, and toxicity of Nepeta menthoides by focusing on the data from the year 1980 until the May $30^{\text {th }} 2018$ via papers on databases including PubMed, Scopus, Google Scholar, Web of Science, and SID (a Persian scientific database). The keywords "Nepeta menthoides" and "Ostokhodus" were used for the search.

\section{Nepeta menthoides in traditional medicine}

Nepeta menthoides is an endemic species of the genus Nepeta in Iran which is distributed in the northwest of the country. Nepeta menthoides is named "ostokhodus" in Persian traditional medicine and herbal stores (10). Ostokhodus or stoechas is one of the oldest herbs mentioned in TPM books and has been represented by several herbs during the time. Today Nepeta menthoides is used as ostokhodus in herbal markets of Iran and traditional medicine because its therapeutic effects are similar to those of ostokhodus in TPM books $(13,14)$.

Ostokhodus has been mentioned in TPM books for reinforcing the major organs including brain, heart and liver, and considered as one of the brain-targeted medications based on TPM concepts. There are TPM indications of ostokhodus including amnesia, sadness and depression, obsession, epilepsy and melancholy. In addition, based on TPM theories some ailments of the other organs such as gastric disorders and respiratory problems including cough and catarrh are related to the brain disorders, and with this viewpoint, ostokhodus has also been recommended for these diseases in TPM $(12,15)$.

\section{Pharmacological profile}

Different pharmacological effects of $N$. menthoides have been reported in in vitro, in vivo and clinical studies. These pharmacological activities have been summarized in Table 1.

\section{Phytochemistry}

Various types of chemical constituents such as monoterpene derivatives, sesquiterpenes, diterpenes, triterpenes, phenolic compounds such as flavonoids, phenolic acids, and some other constituents have been identified in Nepeta species (16-18). Phytochemical screening tests of $N$. menthoides have been shown to be positive for triterpene, sterol, saponin and flavonoid $(10,19,20)$. The names, chemical structure and sources of identified compounds are collected in Table 2. As can be seen from the Table, terpenoids and flavonoids are dominant constituents within this plant.

\section{Anti-infective properties}

A number of reports have been published on the antibacterial effects of $N$. menthoides extracts or its oil. Methanol extract from aerial parts of $N$. menthoides showed significant antibacterial activity against the gram-positive bacteria: Staphylococcus epidermidis, Staphylococcus saprophyticus, Staphylococcus aureus and Bacillus cereus. However, aqueous extracts of the plant had no antibacterial activity (20). A poor inhibitory activity of methanol extracts from N. menthoides root and leaves was observed against Bordetella bronchiseptica and Staphylococcus aureus respectively. $(21,22)$. In addition, $N$. menthoides essential oil from aerial parts and its crude methanolic extract have been shown to have larvicidal activity against Anopheles stephensi with LC50 $=234.3 \mathrm{ppm}$ and LC50 $=69.5 \mathrm{ppm}$, respectively. The authors indicated that nepetalactone isomers and 1,8 cineol must be mentioned as effective compounds related to larvicidal activity (8). Moreover, the antibacterial activity of the essential oil of $N$. menthoides and its 2 main constituents, 1,8-cineol (57\%) and $4 a \alpha, 7 \alpha$, 7aa-nepetalactone, was evaluated against Bacillus subtilis, Bacillus cereus, Staphylococcus aureus, Staphylococcus epidermidis, Enterococcus faecalis, Klebsiella pneumonia, and Escherichia coli (23).

\section{Antioxidant activity}

The antioxidant effect of the essential oil from $N$. menthoides was investigated by Kahkeshani et al (24). The authors demonstrated its effects by two different methods: DPPH and FRAP assays and concluded that the antioxidant activity of the essential oil may partly be 
Table 1. Pharmacological evidence of Nepeta menthoides

\begin{tabular}{|c|c|c|c|c|c|c|}
\hline $\begin{array}{l}\text { Pharmacological } \\
\text { activity }\end{array}$ & Plant part & Assay & $\begin{array}{l}\text { Extract/ essential oil/ } \\
\text { isolated component }\end{array}$ & $\begin{array}{l}\text { Dose or } \\
\text { concentration }\end{array}$ & Observations & Ref. \\
\hline & \multirow{3}{*}{ Aerial parts } & \multirow{3}{*}{ Disc diffusion } & Methanolic extract & ND & $\begin{array}{l}\text { Noticeable activity against the gram-positive bacteria: Staphylococcus epidermidis, Staphylococcus } \\
\text { saprophyticus, Staphylococcus aureus and Bacillus cereus (DIZ: } 36 \mathrm{~mm}, 35 \mathrm{~mm}, 40 \mathrm{~mm} \text {, and } 21 \mathrm{~mm} \\
\text { respectively). } \\
\text { No effect on Pseudomonas aeruginosa, Escherichia coli, and Klebsiella oxytoca } \\
\text { Positive controls: vancomycin and gentamycin }\end{array}$ & \multirow{3}{*}{ (20) } \\
\hline & & & Chloroform extract & ND & $\begin{array}{l}\text { Activity against Staphylococcus epidermidis, Staphylococcus saprophyticus, Staphylococcus aureus and } \\
\text { Klebsiella oxytoca (DIZ: } 13 \mathrm{~mm}, 11 \mathrm{~mm}, 12 \mathrm{~mm} \text {, and } 10 \mathrm{~mm} \text { respectively) } \\
\text { No effect on Pseudomonas aeruginosa, Escherichia coli, and Bacillus cereus } \\
\text { Positive controls: vancomycin and gentamycin }\end{array}$ & \\
\hline & & & Aqueous extract & ND & Had no antibacterial activity & \\
\hline & Root & Agar well diffusion & Methanolic extract & $20 \mathrm{mg} / \mathrm{mL}$ & $\begin{array}{l}\text { Activity against Bordetella bronchiseptica (MIC: } 15 \mu \mathrm{g} / \mathrm{mL} \text { ) } \\
\text { Micrococcus luteus, Klebsiella pneumonia, and Serratia marcescens were resistant to N. menthoides }\end{array}$ & (21) \\
\hline & Leaf & Agar well diffusion & Methanolic extract & $20 \mathrm{mg} / \mathrm{mL}$ & $\begin{array}{l}\text { Poor activity against Staphylococcus aureus (PTCC No: 1337), DIZ: mm } \\
\text { No activity against Staphylococcus aureus (PTCC No: } 1112 \text { and 1113) }\end{array}$ & (22) \\
\hline \multirow{4}{*}{$\begin{array}{l}\text { Anti-infective } \\
\text { properties }\end{array}$} & Aerial parts & WHO method & Essential oil & $\begin{array}{l}80,120,180 \\
270,405 \mathrm{ppm}\end{array}$ & $\begin{array}{l}\text { In concentration of } 405 \mathrm{ppm} \text { showed } 100 \% \text { mortality } \\
\mathrm{LC}_{50}: 234.3 \mathrm{ppm}, \mathrm{LC}_{90}: 419.9 \mathrm{ppm}\end{array}$ & (8) \\
\hline & \multirow{3}{*}{ Aerial parts } & \multirow{3}{*}{ Disc diffusion } & Essential oil & $10 \mu \mathrm{L} /$ disc & $\begin{array}{l}\text { Activity against seven bacteria (Bacillus subtilis, Bacillus cereus, Staphylococcus aureus, Staphylococcus } \\
\text { epidermidis, Enterococcus faecalis, Klebsiella pneumonia, Escherichia coli) with MIC values in the range } \\
\text { of } 1.8-7.2 \mathrm{mg} / \mathrm{mL} \\
\text { Positive control: Ampicillin }\end{array}$ & \multirow{3}{*}{ (23) } \\
\hline & & & 1,8-Cineole & $10 \mu \mathrm{L} /$ disc & $\begin{array}{l}\text { Activity against seven bacteria (Bacillus subtilis, Bacillus cereus, Staphylococcus aureus, Staphylococcus } \\
\text { epidermidis, Enterococcus faecalis, Klebsiella pneumonia, Escherichia coli) with MIC values in the range } \\
\text { of } 0.9-7.2 \mathrm{mg} / \mathrm{mL} \\
\text { Positive control: Ampicillin }\end{array}$ & \\
\hline & & & $\begin{array}{l}\text { 4a } \alpha-7 \alpha-7 a \alpha- \\
\text { Nepetalactone }\end{array}$ & $10 \mu \mathrm{L} /$ disc & $\begin{array}{l}\text { Activity against seven bacteria (Bacillus subtilis, Bacillus cereus, Staphylococcus aureus, Staphylococcus } \\
\text { epidermidis, Enterococcus faecalis, Klebsiella pneumonia, Escherichia coli) with MIC values in the range } \\
\text { of } 1.8-15 \mathrm{mg} / \mathrm{mL} \\
\text { Positive control: Ampicillin }\end{array}$ & \\
\hline
\end{tabular}


Table 1. Continued

\begin{tabular}{|c|c|c|c|c|c|c|}
\hline $\begin{array}{l}\text { Pharmacological } \\
\text { activity }\end{array}$ & Plant part & Assay & $\begin{array}{l}\text { Extract/ essential oil/ } \\
\text { isolated component }\end{array}$ & $\begin{array}{l}\text { Dose or } \\
\text { concentration }\end{array}$ & Observations & Ref. \\
\hline $\begin{array}{l}\text { Antioxidant } \\
\text { activity }\end{array}$ & Aerial parts & DPPH and FRAP method & Essential oil & $\begin{array}{l}10,20,40,80 \\
100 \mu \mathrm{g} / \mathrm{mL}\end{array}$ & $\mathrm{IC}_{50}$ of DPPH test and FRAP value were $28.363 \mu \mathrm{g} / \mathrm{mL}$ and $68.902 \pm 1.37 \mu \mathrm{mol}$ Fe $2+/ \mathrm{g}$ dry plant & (24) \\
\hline \multirow{3}{*}{$\begin{array}{l}\text { Antidepressant } \\
\text { and anxiolytic } \\
\text { activity }\end{array}$} & \multirow{3}{*}{ Aerial parts } & $\begin{array}{l}\text { Beck and Hamilton } \\
\text { depression inventories }\end{array}$ & Crystalline powder & $\begin{array}{l}400 \mathrm{mg} \\
\text { (capsule) }\end{array}$ & N. menthoides could be effective in depressed patients & $(26)$ \\
\hline & & Beck Depression Inventory-II & $\begin{array}{l}\text { Freeze-dried powder of } \\
\text { aqueous extract }\end{array}$ & $\begin{array}{l}400 \mathrm{mg} \\
\text { (capsule) }\end{array}$ & $\begin{array}{l}N . \text { menthoides had benefit effects in the control of mood in major depression and showed a significant } \\
\text { lower recurrence rate }\end{array}$ & $(27)$ \\
\hline & & Beck anxiety inventory & $\begin{array}{l}\text { Freeze-dried powder of } \\
\text { aqueous extract }\end{array}$ & $\begin{array}{l}400 \mathrm{mg} \\
\text { (capsule) }\end{array}$ & $\begin{array}{l}\text { N. menthoides could be effective in the treatment of anxiety in patients with depression and had lower } \\
\text { symptom recurrence rate }\end{array}$ & $(28)$ \\
\hline $\begin{array}{l}\text { Sedative-hypnotic } \\
\text { effects }\end{array}$ & Aerial parts & $\begin{array}{l}\text { Righting reflex test } \\
\text { Open field test }\end{array}$ & Ethanolic extract & $100-800 \mathrm{mg} / \mathrm{kg}$ & N. menthoides could reduce the locomotor activity & (29) \\
\hline \multirow{3}{*}{$\begin{array}{l}\text { Anticholinesterase } \\
\text { activity }\end{array}$} & Aerial parts & Mata method & Essential oil & $\begin{array}{l}25,50,75,100 \\
\mu \mathrm{g} / \mathrm{mL}\end{array}$ & The essential oil had desirable activity with IC50 value of $64.870 \mu \mathrm{g} / \mathrm{mL}$ & (24) \\
\hline & $\begin{array}{l}\text { Flowering } \\
\text { part }\end{array}$ & Ellman's method & $\begin{array}{l}\text { Methanol extract, } \\
\text { Dichloromethane extract }\end{array}$ & $10 \mathrm{mg} / \mathrm{mL}$ & Showed AchE inhibitory activity & (32) \\
\hline & Aerial parts & Ellman's method & Essential oil, 1,8-cineole & $25 \mu \mathrm{L}$ & Showed AchE inhibitory activity & (33) \\
\hline \multirow{3}{*}{$\begin{array}{l}\text { Neuroprotective } \\
\text { effect }\end{array}$} & \multirow{3}{*}{ Aerial parts } & TUNEL assay & Ethanolic extract & $\begin{array}{l}250,500,1000 \\
\mathrm{mg} / \mathrm{kg}\end{array}$ & N. menthoides showed neuroprotective effects in a dose-dependent manner & (37) \\
\hline & & TUNEL assay & Ethanolic extract & $\begin{array}{l}250,500,1000 \\
\mathrm{mg} / \mathrm{kg}\end{array}$ & Administration of $N$. menthoides before neural injury causes no more neuroprotective effect. & (38) \\
\hline & & TUNEL assay & Ethanolic extract & $250,500 \mathrm{mg} / \mathrm{kg}$ & N. menthoides induced neuroprotective effect on axotomized sensory neurons in dorsal root ganglion & (39) \\
\hline
\end{tabular}


Table 1. Continued

\begin{tabular}{|c|c|c|c|c|c|c|}
\hline $\begin{array}{l}\text { Pharmacological } \\
\text { activity }\end{array}$ & Plant part & Assay & $\begin{array}{l}\text { Extract/ essential oil/ } \\
\text { isolated component }\end{array}$ & $\begin{array}{l}\text { Dose or } \\
\text { concentration }\end{array}$ & Observations & Ref. \\
\hline \multirow{3}{*}{$\begin{array}{l}\text { Memory } \\
\text { enhancing effects }\end{array}$} & Aerial parts & Y-maze task & $\begin{array}{l}\text { Aqueous extract, Hydro- } \\
\text { alcoholic extract }\end{array}$ & $\begin{array}{l}50,100,150 \\
\mathrm{mg} / \mathrm{kg}\end{array}$ & N. menthoides had memory enhancing effect in mice & (34) \\
\hline & Leaf & $\begin{array}{l}\text { Passive avoidance down step } \\
\text { model }\end{array}$ & Aqueous extract & $\begin{array}{l}100,200,400 \\
800 \mathrm{mg} / \mathrm{kg}\end{array}$ & N. menthoides had memory enhancing effect in mice & (35) \\
\hline & Aerial parts & Morris water maze task & Aqueous extract & $100,500 \mathrm{mg} / \mathrm{kg}$ & $\begin{array}{l}N . \text { menthoides reversed the destructive effect of chronic cold-water-induced hypothermia on learning } \\
\text { and memory in rats }\end{array}$ & (36) \\
\hline Anti-Alzheimer's & Aerial parts & MMSE inventories & Hydro-alcoholic extract & $\begin{array}{l}500 \mathrm{mg} \\
\text { (capsule) }\end{array}$ & N. menthoides had positive influence on the treatment of Alzheimer disease & (31) \\
\hline \multirow[t]{2}{*}{ Cytotoxic activity } & \multirow[t]{2}{*}{ Aerial parts } & \multirow[t]{2}{*}{ MTT test } & Essential oil & $\begin{array}{l}50,100,250 \\
500,1000 \mu \mathrm{g} / \\
\mathrm{mL}\end{array}$ & N. menthoides showed a significant effect against T47D, HT-29 and Caco-2 cell lines & (24) \\
\hline & & & Essential oil, 1,8-cineole & $25 \mu \mathrm{L}$ & $\begin{array}{l}\text { Essential oil and 1,8-cineole showed a significant effect against three breast cancer cell lines (MCF-7, } \\
\text { T47D and MDA-MB-231) }\end{array}$ & (33) \\
\hline $\begin{array}{l}\text { Effect on opioid } \\
\text { dependence and } \\
\text { tolerance }\end{array}$ & Aerial parts & Chimney test & Hydro-alcoholic extract & $200,400 \mathrm{mg} / \mathrm{kg}$ & $\begin{array}{l}\text { N. menthoides could dose-dependently attenuate the development of dependence in morphine-treated } \\
\text { mice and potentiated morphine anti-nociceptive effect }\end{array}$ & (40) \\
\hline
\end{tabular}

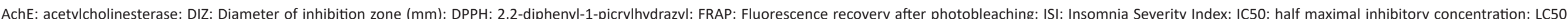

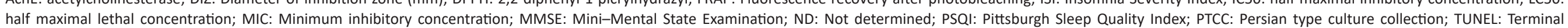
deoxynucleotidyl transferase dUTP nick end labeling; WHO: World Health Organization 
Table 2. Chemical compounds of Nepeta menthoides

\begin{tabular}{|c|c|c|c|}
\hline Name of compound & Chemical structure & Plant part & References \\
\hline 1, 8-cineole & & $\begin{array}{l}\text { Leaves and flowers } \\
\text { Flowering shoots } \\
\text { Aerial parts }\end{array}$ & $\begin{array}{l}(4,7,8,10,18,19,23, \\
37,42,43)\end{array}$ \\
\hline Dihydromyrcenol & & Leaves and flowers & (4) \\
\hline $\begin{array}{l}\text { 4-terpineol } \\
\text { (Terpinen-4-ol) }\end{array}$ & & $\begin{array}{l}\text { Leaves and flowers } \\
\text { Flowering shoots }\end{array}$ & $(4,7)$ \\
\hline Geranyl acetate & & $\begin{array}{l}\text { Leaves and flowers } \\
\text { Flowering shoots } \\
\text { aerial parts }\end{array}$ & $(4,7,10,19)$ \\
\hline $\begin{array}{l}4 \mathrm{a} \alpha, 7 \alpha, 7 \mathrm{a} \alpha- \\
\text { nepetalactone }\end{array}$ & & $\begin{array}{l}\text { Flowering shoots } \\
\text { aerial parts }\end{array}$ & $(7,8,10,18,23)$ \\
\hline Neryl acetate & & Flowering shoots & (7) \\
\hline$\beta$-Pinene & & $\begin{array}{l}\text { Flowering shoots } \\
\text { leaves and flowers } \\
\text { aerial parts }\end{array}$ & $(7,19,40)$ \\
\hline$\alpha$-Pinene & & Aerial parts & (40) \\
\hline$\alpha$-Terpineol & & $\begin{array}{l}\text { leaves and flowers } \\
\text { aerial parts }\end{array}$ & $(7,40)$ \\
\hline$\alpha$-Linalool & & aerial parts & (18) \\
\hline
\end{tabular}


Table 2. Continued

\begin{tabular}{|c|c|c|c|}
\hline Name of compound & Chemical structure & Plant part & References \\
\hline $\mathrm{\gamma}$-Terpinene & & Aerial parts & (40) \\
\hline Rosmarinic acid & & Aerial parts & (44) \\
\hline Isothymusin & & Aerial parts & (18) \\
\hline $\begin{array}{l}\text { 6-Methoxy-7-O-methyl } \\
\text { apigenin (cirsimaritin) }\end{array}$ & & Aerial parts & (18) \\
\hline $\begin{array}{l}\text { 7-O-Methyl apigenin } \\
\text { (genkwanin) }\end{array}$ & & Aerial parts & (18) \\
\hline
\end{tabular}

attributed to its components like myrcene, 1,8-cineole, limonene, $\alpha$-terpinene and $\alpha$-terpinolene. Moreover, this activity may play a crucial role in protecting cells from oxidative stress and disease prevention.

Anti-Inflammatory and anti-nociceptive activities A hydroalcoholic extract of $N$. menthoides was reported to possess anti-nociceptive and anti-inflammatory activities as evidenced by effects in formalin test, hot water tailimmersion test and xylene induced ear oedema in mice. The study reported that $N$. menthoides aerial parts had anti-inflammatory effect at all tested doses, particularly at dose of $2800 \mathrm{mg} / \mathrm{kg}$. Also, it caused a significant reduction of pain in the formalin test (acute and chronic phases) and the dose of $2800 \mathrm{mg} / \mathrm{kg}$ had the highest anti-nociceptive effect in chronic phases. Meanwhile, N. menthoides hydroalcoholic extract showed an acceptable analgesic effect in the tail immersion test. These effects might be due to its constituents: Nepetalactone and 1,8 cineole (25).

Antidepressant and anxiolytic activities

Nepeta menthoides aerial parts have been shown to possess antidepressant activity in an 8-week triple-blind randomized controlled trial study. In this study, fifteen patients received only $N$. menthoides capsules (400 mg) and fifteen patients treated with $N$. menthoides capsules and conventional drugs. Pharmaceutical capsules of $N$. menthoides could be potentially effective in depressed patients (26). In parallel, Kolouri et al assessed the effectiveness of $N$. menthoides in the treatment of major depression (MD). The results of this double blind randomized controlled trial study showed that in a short-term therapy, patients with MD receiving capsules containing $400 \mathrm{mg}$ freeze-dried powder of $N$. menthoides aqueous extract experienced a significant reduction in their Beck Depression Inventory (BDI) scores after four 
weeks of treatment compared with the standard treatment group (sertraline). Furthermore, two weeks follow up after intervention showed a statistically significant lower recurrence rate in the $N$. menthoides group (27). The anxiolytic activity of $N$. menthoides was investigated by evaluating its influence on the Beck anxiety inventory (BAI) score in patients with depression. The $N$. menthoides group who received freeze- dried aqueous extract formulation (400 mg/BID) demonstrated a greater reduction of BAI score and lower symptom recurrence rate as compared to the sertraline group. Moreover, the prevalence of reported side effects was lower in the $N$. menthoides than the SSRI group (28). These studies demonstrated the effects of $N$. menthoides on depression and anxiety induced by monoterpenes, sesquiterpenes, polyphenolic compounds and flavonoids. The findings of these studies suggested that $N$. menthoides might be an effective and safe treatment for depression and anxiety along with conventional medications.

Sedative-hypnotic effects

In an effort to find new effective substances that relieve insomnia while avoiding side effects, numerous studies tending to focus on herbal medicines have been done. In 2012, Bozorgmehr et al reported a sedative effect for the ethanolic extract of $N$. menthoides (29). N. menthoides (freeze-dried aqueous extract) has been shown to possess hypnotic effect. In this triple-blind randomized placebo controlled study, the subjects received three $500 \mathrm{mg}$ capsules containing $1000 \mathrm{mg}$ Melissa officinalis plus $400 \mathrm{mg}$ of $\mathrm{N}$. menthoides nightly for four weeks. The results showed that the Insomnia Severity Index (ISI) significantly decreased in treatment group and the patients who received herbal treatment experienced a significant improvement in their total sleep time as compared to the placebo group (30).

\section{Effect on cognition and memory}

The efficacy of $N$. menthoides extract in the treatment of patients with Alzheimer's disease was assessed in a clinical trial. The study was performed on two groups of $\mathrm{AD}$ patients. While the first group was prescribed the oral capsule $(500 \mathrm{mg}$ ) of Nepeta extraction, the second group was given the placebo capsules $(500 \mathrm{mg}$ ). Both groups were prescribed the conventional Alzheimer medications as the primary drugs. The remarkable improvement in the MMSE (Mini-Mental State Examination) scores in patients who received oral capsule of $N$. menthoides, three times daily, emphasized the potential of this plant accompanied by the conventional medications in decreasing the $\mathrm{AD}$ symptoms (31). Furthermore, some pharmacological evidence has been indicated the anticholinesterase activity, and memory enhancing effects of $N$. menthoides in vivo and in vitro.

Essential oil from N. menthoides aerial parts was found to inhibit the acetylcholinesterase enzyme (AChE). In AchE inhibitory test, the essential oil had desirable anticholinesterase activity with IC50 value of $64.870 \mu \mathrm{g} /$ $\mathrm{mL}$. 1,8-cineol, the greatest percentage composition of N. menthoides essential oil, is a potent inhibitor of AchE which plays a major role in inhibiting the enzyme (24). Moreover, AchE inhibitory activity of $N$. menthoides was also measured in a study conducted by Adhami et al. Both the methanol and dichloromethane extract showed significant AchE inhibitory effect (32). More recent studies showed the significant inhibition of AchE activity by essential oil and 1,8-cineole from $N$. menthoides. 1,8-Cineole exhibited higher inhibitory than the essential oil and both of them were more potent than rivastigmine (33). Taken together, these findings implicate that $N$. menthoides would be excellent candidate for future Alzheimer's disease therapy.

Behavioral studies have demonstrated that $N$. menthoides extract affects learning and memory in experimental animals. Hydroalcoholic extract of $N$. menthoides was reported to improve scopolamine-induced impairments of memory retention and retrieval in Y-maze task in mice (34). In similar work, Sarahroodi et al (35) demonstrated that the aqueous extract of $N$. menthoides leaves had promising memory enhancing effects at dose of $800 \mathrm{mg} /$ $\mathrm{kg}$ using passive avoidance down step model. The presence of antioxidants such as rosmarinic acid, luteolin, cinnamic acid derivatives, caffeic acid, tocopherols, phenolic acids and coumarins can be a major contributor to the memoryenhancing effects of $N$. menthoides extract. Moreover, the water extract of $N$. menthoides was found to reverse the destructive effect of chronic cold-water-induced hypothermia on learning and memory in rats. The results showed that lower dose of $N$. menthoides neutralized learning and memory impairment, but higher dose had adverse effects on learning. Moreover, the extract could reduce hyperphosphorylation of tau protein that seems to be one of the mechanisms of its anti-dementia activities (36).

\section{Neuroprotective effects}

Different doses of $N$. menthoides were investigated for neuroprotective activity. It was observed that intraperitoneal administration of axotomized rats with ethanolic extract of $N$. menthoides resulted in an increased survival of axotomized motoneurons and a decreased apoptotic rate in a dose-dependent manner which was most prominent with the dose of $500 \mathrm{mg} / \mathrm{kg}$ (37). However, the study on prophylactic capacity of $N$. menthoides revealed that administration of $N$. menthoides ethanolic extract before neural injury causes no more neuroprotective effect on axotomized motoneurons (38). In another study, alcoholic extract of $N$. menthoides aerial parts by virtue of its anti-apoptotic effects induced neuroprotective effect on axotomized sensory neurons in dorsal root ganglion 
(DRG) of neonate rats by attenuating the apoptotic cell death (39). The results confirm the traditional use of this plant for the treatment of neural disorders such as epilepsy and melancholia (12).

Cytotoxic activity

The anti-proliferative effects of essential oil of $N$. menthoides were investigated in colon carcinoma (HT29), colorectal adeno-carcinoma (Caco-2), breast ductal carcinoma (T47D) cell lines and the Swiss mouse embryo fibro blast (NIH-3T3) as a normal cell line using the MTT method. As the IC50 value for the normal cell line was low, the MTT test showed that the essential oil exhibited the highest cytotoxic activity against T47D followed by HT-29 and Caco- 2 cell lines with the IC50 values of $19.37 \pm 4.92$, $30.7 \pm 7.36$ and $32.24 \pm 5.98 \mu \mathrm{g} / \mathrm{mL}$, respectively. This cytotoxic activity of $N$. menthoides might be observed due to specific components like $\alpha$-terpineol, terpinolene, 1,8-cineole and limonene (24). In 2018, Kahkeshani et al studied the inhibitory effects of the essential oil and 1,8-cineole isolated from $N$. menthoides against three breast cancer cell lines (MCF-7, T47D and MDAMB-231). Both compounds displayed inhibitory activity, but the essential oil was more cytotoxic than 1,8-cineole to breast cancer cell lines (33).

Effect on opioid dependence and tolerance

Chronic pretreatment with $N$. menthoides hydro-alcoholic extract could dose-dependently attenuate the development of dependence in morphine-treated mice. Furthermore, $N$. menthoides prevented the acquisition of morphine tolerance and potentiated morphine analgesic effect in a synergistic manner. It appears that inhibition of the nitric oxide (NO) overproduction is the main mechanism responsible for these effects of $N$. menthoides (40).

\section{Toxicity and safety}

Nepeta menthoides has been widely used in Persian traditional medicine. Although previous clinical studies on this herb have reported no significant adverse effects, some clinical and experimental studies have shown that $N$. menthoides has mild to moderate side effects. In one clinical trial anorexia, bulimia, xerostomia, emesis, impotence, and drowsiness were the most commonly side effects reported by the patients and one patient stopped $N$. menthoides capsules due to severe dermal irritation $[16,28]$. Moreover, N. menthoides was found to increase susceptibility to seizures (41).

\section{Discussion}

Ostokhodus, one of the oldest herbs in Iran, had been widely introduced in TPM textbooks for treating various ailments. This herb has been substituted with other herbs with similar therapeutic effects over the time. Since 20 century the plant $N$. menthoides has been utilized as ostokhodus in Iran by people for different medicinal effects. This review collected findings about phytochemical and pharmacological properties of $N$. menthoides and presented comprehensive analysis of researches published since the year 2000. Ethnopharmacological published data about this herb is rare because of limited distribution as an endemic plant in Iran. Despite the lack of comprehensive pharmacological studies on $N$. menthoides, this plant is widely used in traditional medicine as antinociceptive, anti-Alzheimer's disease, memory enhancer, neuroprotective, antidepressant and anxiolytic agent. It seems that more preclinical studies are needed to assess this herb clinically specially in the field of seizure because one study indicated the increased susceptibility to seizures. Moreover, there are several medicinal properties discussed in Persian medicine such as anti-tussive, gastrotonic and gastrointestinal effects which are not supported by any modern scientific evidence and N. menthoides should also be assessed in these fields.

Despite high consumption of this plant, little phytochemical and quality control studies have been done on it. However, with respect to the limited published phytochemical assays, triterpenes and monoterpenes are the most abundant constituents of the essential oil of $N$. menthoides.

\section{Conclusion}

Considering the medicinal properties of isolated components, it can be concluded that terpenoids might be associated with anti-inflammatory and antimicrobial activities. Also, antioxidant and anticancer activities could be related to its phenols and flavonoids. Many of the phytochemical studies on this herb are based on essential oil analysis; hence there is still a huge need for extensive analysis on its different extracts.

\section{Authors' contributions}

All the authors contributed in data collection and preparation of the manuscript. All authors read the final version and confirmed for the publication.

\section{Conflict of interests}

The authors declare that they have no conflict of interests.

\section{Ethical considerations}

Ethical issues have been observed by the authors.

\section{Funding/Support}

None.

\section{References}

1. Zargari A. Medicinal plants. Tehran, Iran: Tehran University Publications; 1995.

2. Raja RR. Medicinally potential plants of Labiatae (Lamiaceae) family: an overview. Research Journal 
of Medicinal Plants. 2012;6(3):203-13. doi: 10.3923/ rjmp.2012.203.213.

3. Jamzad Z, Ingrouille M, Simmonds MSJ. Three new species of Nepeta (Lamiaceae) from Iran. Taxon. 2003;52(1):93-8. doi: $10.2307 / 3647304$.

4. Mojab F, Nickavar B, Hooshdar Tehrani H. Essential Oil Analysis of Nepeta crispa and N. menthoides from Iran. Iranian Journal of Pharmaceutical Sciences. 2009;5(1):43-6.

5. Acar M, Ozcan T, Satil F, Dirmenci T. A comparative anatomical study on two endemic Nepeta L. species (N. baytopii and N. sorgerae). Biological Diversity and Conservation. 2011;4(3):58-70.

6. Sajjadi SE. Analysis of the essential oil of Nepeta sintenisii Bornm. from Iran. Daru. 2005;13(2):61-4.

7. Nazemieh H, Razavi SM, Asnaashari S, Talebpour AH, Ghahramani M, Imani Y. Chemical composition of the essential oil of Nepeta menthoides Boiss \& Buhse. Pharmaceutical Sciences. 2009;14(4):283-9.

8. Khanavi M, Fallah AR, Vatandoost H, Sedaghat M, Abai MR, Hadjiakhoondi A. Larvicidal activity of essential oil and methanol extract of Nepeta menthoides against malaria vector Anopheles stephensi. Asian Pac J Trop Med. 2012;5(12):962-5. doi: 10.1016/s1995-7645(12)60182-5.

9. Nunez D, De Castro CO. Palaeoethnobotany and archaeobotany of the Labiatae in Europe and the near East. Advances in Labiatae Science. Royal Botanic Gardens; 1992. p. 437.

10. Kahkeshani N, Khanavi M, Hadjiakhoondi A. Quality Control of Nepeta menthoides Boiss \& Buhse using Micromorphological Analysis and Phytochemical Screening. Journal of Medicinal Plants. 2014;1(49):34-8.

11. Amini A. Illustrated dictionary of therapeutic plants and their traditional usage in Kurdistan. Khoramabad: Taqbostan Publication; 1997.

12. Aghili A. The Institue of Medical History, Islamic and Complementary Medicine Studies. Tehran: Makhzan ulAdvia; 2008.

13. Farsam H, Ahmadian Attari S, Khalaj A, Kamalinejad M, Shahrokh R, Ahmadian-Attari MM. The Story of Stoechas: from Antiquity to the Present Day. Journal of Research on History of Medicine. 2016;5(2):69-86

14. Ghorbani A, Mohammadi S. Review on the ethnobotany of Labiatae family in Iran. Iran J Pharm Res. 2010;64-9.

15. Shoja T, Shamsi M, Changizi Ashtiyani S, Ramezani M, Aalizadeh A. An overview of the ideas of the traditional medical scholars on the symptoms, causes and treatment of nasal catarrh and post nasal drip. American Journal of Ethnomedicine. 2015;2(1):46-52.

16. Naghibi F, Mosaddegh M, Mohammadi Motamed M, Ghorbani A. Labiatae family in folk medicine in Iran: from ethnobotany to pharmacology. Iran J Pharm Res. 2010;4(2):63-79. doi: 10.22037/ijpr.2010.619.

17. Asgarpanah J, Sarabian S, Ziarati P. Essential oil of Nepeta genus (Lamiaceae) from Iran: a review. J Essent Oil Res. 2014;26(1):1-12. doi: 10.1080/10412905.2013.851040.

18. Formisano C, Rigano D, Senatore F. Chemical constituents and biological activities of Nepeta species. Chem Biodivers. 2011;8(10):1783-818. doi: 10.1002/cbdv.201000191.

19. Baiazandeh MM. Essential oil composition of Nepeta menthoides Boiss. et Bushe from Iran. J Essent Oil Res.
2006;18(2):144-5. doi: 10.1080/10412905.2006.9699046.

20. Ghandchi S, Jamzad M. Total flavonoids contents and anti bacterial activity of the extracts of two Labiateae species: Nepeta menthoides and Thymus trautvetteri. Journal of Medicinal plants and By-product. 2015;4(1):77-82.

21. Shahidi Bonjar GS. Evaluation of antibacterial properties of Iranian medicinal-plants against Micrococcus luteus, Serratia marcescens, Klebsiella pneumoniae and Bordetella bronchoseptica. Asian J Plant Sci. 2004;3(1):82-6. doi: 10.3923/ajps.2004.82.86.

22. Shahidi Bonjar GS. Inhibition of three isolates of Staphylococcus aureus mediated by plants used by Iranian native people. J Med Sci. 2004;4:136-41. doi: 10.3923/ jms.2004.136.141.

23. Sonboli A, Gholipour A, Yousefzadi M, Mojarrad M. Antibacterial activity and composition of the essential oil of Nepeta menthoides from Iran. Nat Prod Commun. 2009;4(2):283-6.

24. Kahkeshani N, Razzaghirad Y, Ostad SN, Hadjiakhoondi A, Shams Ardekani MR, Hajimehdipoor H, et al. Cytotoxic, Acetylcholinesterase Inhibitor and Antioxidant Activity of Nepeta menthoides Boiss \& Buhse essential oil. Journal of Essential Oil Bearing Plants. 2014;17(4):544-52. doi: 10.1080/0972060X.2014.929040.

25. Asadi Balsin Sharif Abadil S, Nasri S, Amin G, Bidaran S. Anti-inflammatory and anti-nociceptive effects of hydroalchoholic extract of Nepeta menthoides on pain in aerial parts in male mice. Journal of Jahrom University of Medical Sciences. 2013;11(3):1-9. doi: 10.29252/jmj.11.3.1.

26. Firoozabadi A, Zarshenas MM, Salehi A, Jahanbin S, Mohagheghzadeh A. Effectiveness of Cuscuta planiflora Ten. and Nepeta menthoides Boiss. \& Buhse in major depression: a triple-blind randomized controlled trial study. J Evid Based Complementary Altern Med. 2015;20(2):94-7. doi: $\quad 10.1177 / 2156587214557359$.

27. Kolouri S, Firoozabadi A, Salehi A, Zarshenas MM, Dastgheib SA, Heydari M, et al. Nepeta menthoides Boiss. \& Buhse freeze-dried aqueous extract versus sertraline in the treatment of major depression: A double blind randomized controlled trial. Complement Ther Med. 2016;26:164-70. doi: 10.1016/j.ctim.2016.03.016.

28. Firoozabadi A, Kolouri S, Zarshenas MM, Salehi A, Mosavat SH, Dastgheib SA. Efficacy of Nepeta Menthoides Boiss and Buhse freeze-dried aqueous extract on anxiety of patients with depression: a double-blind randomized controlled clinical trial. Iran J Med Sci. 2016;41(3 Suppl):S4.

29. Bozorgmehr B, Mojab F, Faizi M. Evaluation of sedativehypnotic effect of ethanolic extract of five medicinal plants; Nepeta menthoides, Matricaria chamomilla, Asperugo procumbens, Lippia citriodora and Withania somnifera. Res Pharm Sci. 2012;7(5):S831.

30. Ranjbar M, Salehi A, Rezaeizadeh H, Zarshenas MM, Sadeghniiat-Haghighi K, Mirabzadeh M, et al. Efficacy of a Combination of Melissa officinalis L. and Nepeta Menthoides Boiss. \& Buhse on Insomnia: A Triple-Blind, Randomized Placebo-Controlled Clinical Trial. J Altern Complement Med. 2018;24(12):1197-203. doi: 10.1089/acm.2017.0153.

31. Abdolahadi A, Nazeri A, Esmaeili S, Amiri Z, Movahhed M. Effect of Nepeta menthoides on cognitive disorders in Alzheimer's disease: A clinical trial. Eur Online J Nat Soc 
Sci. 2017;6(2):228-37.

32. Adhami HR, Farsam H, Krenn L. Screening of medicinal plants from Iranian traditional medicine for acetylcholinesterase inhibition. Phytother Res. 2011;25(8):1148-52.

33. Kahkeshani N, Hadjiakhoondi A, Navidpour L, Akbarzadeh T, Safavi M, Karimpour-Razkenari E, et al. Chemodiversity of Nepeta menthoides Boiss. \& Bohse. essential oil from Iran and antimicrobial, acetylcholinesterase inhibitory and cytotoxic properties of 1,8-cineole chemotype. Nat Prod Res. 2018;32(22):2745-8. doi: 10.1080/14786419.2017.1378202.

34. Kiyani N, Kiyani A, Khademizadeh M, Ranjbar Pazuki M, Aliasl Mamghani F, Mozaffari Dehshiri A. Nepeta menthoides as memory enhancer. Planta Med. 2012;78(11):PI449. doi: 10.1055/s-0032-1321136.

35. Sarahroodi S, Jafari-Najafi R, Nasri S, Rohampour K, Maleki-Jamshid A, Esmaeili S. Effects of Nepeta menthoides aqueous extract on retention and retrieval of memory in mice. Pak J Biol Sci. 2012;15(22):1085-9.

36. Ahmadian-Attar MM, Ahmadiani A, Kamalinejad M, Dargahi L, Mosaddegh M. Chronic cold-water-induced hypothermia impairs memory retrieval and Nepeta menthoides as a traditional "hot" herb reverses the impairment. Iran J Pharm Res. 2014;13(Suppl):185-93.

37. Azizzadeh Delshad AR, Naseri M, Parvizi M, Fattah N, Sharayeli M. The Iranian traditional herbal medicine ostokhodus can prevent axotomy-induced apoptosis in spinal motoneurons in neonate rats. J Med Plant Res. 2011;5(18):4446-51.

38. Azizzadeh Delshad AR, Farzan A. The prophylactic capacity of Nepeta menthoides (Ostokhodus) in prevention of spinal motoneuron injury. Journal of Kerman University of Medical Sciences. 2013;20(1):20-30.

39. Azizzadeh Delshad AR, Parvizi M. The neuroprotective effect of Nepeta menthoides on axotomized dorsal root ganglion sensory neurons in neonate rats. J Basic Clin Pathophysiol. 2014;2(2):13-20.

40. Rahmati B, Beik A. Prevention of morphine dependence and tolerance by Nepeta menthoides was accompanied by attenuation of Nitric oxide overproduction in male mice. J Ethnopharmacol. 2017;199:39-51. doi: 10.1016/j. jep.2017.01.032.

41. Heydari A, Rahmati B, Khalili M, Roghani M, Zaeri F. Intensified convulsions induced through intravenous infusion of PTZ by Nepeta menthoides hydroalcoholic extract in mice. Daneshvar Medicine. 2015;23(119):9-20.

42. Kioumarsi M, Imani A. The study of environment conditions on the chemical composition of medicinal species Nepeta Menthoides of Sabalan. Journal of Biodiversity and Environmental Sciences. 2015;6(1):567-72.

43. Omidi M, Imani AA. Investigating the effects of major ecological factors on essential oils and existing chemical compounds of Nepeta menthoides in habitat conditions. Environment Conservation Journal. 2015; 16:457-9.

44. Hadi N, Sefidkon F, Shojaeiyan A, Siler B, Jafari A-A, Anicic $\mathrm{N}$, et al. Phenolics' composition in four endemic Nepeta species from Iran cultivated under experimental field conditions: The possibility of the exploitation of Nepeta germplasm. Ind Crops Prod. 2017;95:475-84. doi: 10.1016/j. indcrop.2016.10.059. 